\title{
Geology of the volcano-sedimentary complex of the Kamyanyi Potik Unit on Chyvchyn Mount (Ukrainian Carpathians): preliminary results
}

\author{
Oleh HNYLKO ${ }^{1, *}$, Michał KROBICKI ${ }^{2,3}$, Anna FELDMAN-OLSZEWSKA ${ }^{4}$, \\ and Jolanta IWAŃCZUK ${ }^{4}$ \\ 1 National Academy of Science of Ukraine, Institute of Geology and Geochemistry of Combustible Minerals, Naukova 3a, \\ 79060 Lviv, Ukraine \\ 2 Polish Geological Institute - National Research Institute, Carpathian Branch, Skrzatów 1, 31-560 Kraków, Poland \\ 3 AGH University of Science and Technology, Al. A. Mickiewicza 30, 30-059 Kraków, Poland \\ 4 Polish Geological Institute - National Research Institute, Rakowiecka 4, 00-975 Warszawa, Poland
}

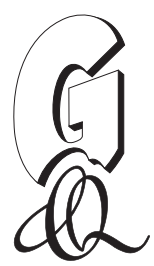

Hnylko, O., Krobicki, M., Feldman-Olszewska, A., Iwańczuk, J., 2015. Geology of the volcano-sedimentary complex of the Kamyanyi Potik Unit on Chyvchyn Mount (Ukrainian Carpathians): preliminary results. Geological Quarterly, 59 (1): 145-156, doi: 10.7306/gq.1220

The Kamyanyi (Kaminnyi) Potik Unit (Nappe) is the most internal and structurally-highest unit of the Fore-Marmarosh units, and in many places is directly covered by the Marmarosh Nappes of the Marmarosh Crystalline Massif. Chyvchyn Mount is built of this unit and forms a separate tectonic cap (Chyvchyn Mt. Klippe). It consists of the Upper Jurassic/lowermost Cretaceous Chyvchyn Formation, composed mainly of basic volcanic rocks, and the Tithonian-Early Cretaceous Kamyanyi Potik Formation, represented by calcareous and/or turbiditic deposits containing volcanic material. Geological mapping showed that this complex forms a tectonic klippe, which consists of four small tectonic thrust slices. Structurally, the lowermost one is represented by thin-bedded micritic limestones with cherts, and is interbedded with coarse/fine-grained calcareous pyroclastic turbidites (flysch). The second thrust slice is composed of calcareous-pyroclastic breccia with blocks of limestone, basalt, and chert (radiolarite?), which occur within a pyroclastic matrix and of coral limestones with basalt fragments and pyroclastic intercalations. The third thrust slice is constructed of breccia with a pyroclastic and volcanic matrix and clasts of effusive rocks and limestone. The fourth thrust slice - the highest - is represented by massive basaltic pillow lavas. Sedimentologically, the volcano-sedimentary complex represents a whole spectrum of marine mass-movement deposits, from debris flows through proximal turbidites to distal ones, which were formed during latest Jurassic/earliest Cretaceous time in the Outer Dacide-Severinide part of the Carpathian basins.

Key words: volcanic rocks, pyroclastic flysch, basaltic pillow lavas, Carpathians, Chyvchyn Mountains, Kamyanyi Potik Unit.

\section{INTRODUCTION}

The Ukrainian Carpathians occupy the junction where several (sub)oceanic sutures converged, such as the PenninicVahic (its fragments are presented in the Pieniny Klippen Belt) and the Meliata-Hallstatt (Meliata) (Plašienka, 1997) sutures in the Western Carpathians, and the Transylvanides (branch of the Vardar Zone; Săndulescu, 2009) and Fore-Marmarosh sutures in the Eastern Carpathians. The Fore-Marmarosh Suture Zone is developed in the Ukrainian Carpathians (Gnylko, 1999; Hnylko, 2011a); its prolongation towards Romanian territory most likely is the Outer Dacides-Severinides (sensu Golonka et

\footnotetext{
* Corresponding author, e-mail: ohnilko@yahoo.com Received: January 15, 2014; accepted: September 8, 2014; first published online: February 4, 2015
}

al., 2008a, b; Săndulescu, 2009). The prolongation of the Transylvanides towards Ukraine is unclear (Fig. 1).

The equivocal correlation of the suture zones in Ukraine has led to the varied tectonic reconstructions in the AlpineCarpathian region (Csontos and Vörös, 2004; Golonka et al., 2006; Schmid et al., 2008; Săndulescu, 2009). For proper correlation, a detailed investigation of the well-exposed basic (ultrabasic) magmatic rocks (possible fragments of ancient oceanic crust) is needed. On Chyvchyn Mt. (in the Ukrainian Carpathians, close to the upper stream of the Chorny Cheremosh River), the volcano-sedimentary complex of rocks is fully developed.

The first detailed geological structure of Chyvchyn Mountains was shown on the geological maps published by Zapałowicz (1886) and Pazdro (1934), however, on these maps the Jurassic/Cretaceous volcano-sedimentary formations of Chyvchyn Mt. were attributed to the Triassic (cf. Książkiewicz and Sokołowski, 1934), but its tectonic-structural position is correctly shown. Fifty years ago, a detailed map of Chyvchyn Mts. (unfortunately unpublished) was compiled by the geologists of the Carpathian expedition of Moscow University (Byzova et al., 


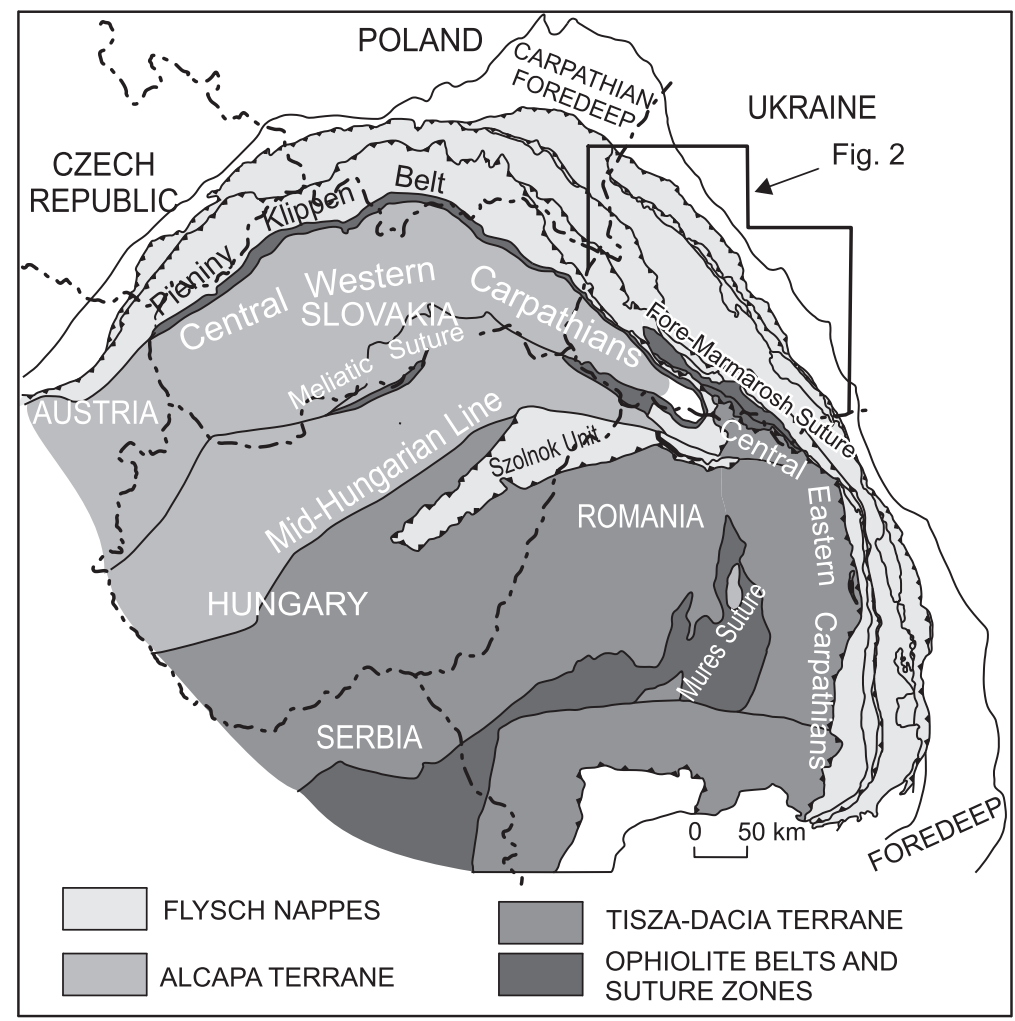

Fig. 1. Tectonic setting of the Ukrainian Carpathians

Main tectonics units (after Kovač et al., 1998; Csontos and Vörös, 2004; Schmid et al., 2008; modified)

1964). The structure of Chyvchyn Mt. was defined there as the tectonic nappe relict (Chyvchyn Mt. Klippe), built by the Juras$\mathrm{sic} /$ Cretaceous volcano-sedimentary rocks that overlie the Cretaceous flysch.

Medvedev and Varitchev (2000) suggested that this klippe may be a remnant of the Transylvanian Nappes (Transylvanides). Recently, geological data from the region were summarized by Matskiv et al. (2009); they related the Jurassic/Cretaceous volcano-sedimentary complex of the Chyvchyn Mt. Klippe to the Kamyanyi Potik Unit (Nappe), developed directly in the front of the Marmarosh Nappes.

The basic volcanic rocks of Chyvchyn Mt. are well-known, owing to studies by many geologists (Lomize, 1968; Lyashkevich et al., 1995; Varitchev, 1997; Medvedev and Varitchev, 2000); some of them aimed to reconstruct the palaeotectonic conditions of the origins of the volcanogenic rocks. The main aim of this work is to show, for the first time in such a detailed view, a map of Chyvchyn Mt. and its vicinity, with a new structural interpretation of a few tectonic thrust slices, and preliminary sedimentological descriptions of the volcano-sedimentary rocks which build them.

\section{GEOLOGICAL BACKGROUND}

The Ukrainian Carpathians form a connecting link between the Western and Eastern Carpathians, but the structure of this connection is disputable. There are two concepts. The first idea assumes that the inner structural-facies units (predominantly nappes) of the Outer (Flysch) Carpathians, such as the Burkut ( $\approx$ Porkulets), Dukla, and Silesian (Krosno) ones, belong to both the eastern and western Carpathians (Kruglov, 1986; Matskiv et al., 2009). In the Ukrainian part of the orogen, these units stretch out from the Uzh River up to Cheremosh River. According to the second concept, the Outer Eastern Carpathians Inner Nappes do not extend from the west to the east Carpathians (Vialov et al., 1981; Jankowski et al., 2007), and this idea is adopted in the present work. It is generally accepted that the Outer Skyba (=Skole, Tarkău) Nappe extends from the western to the eastern Carpathians.

On the basis of previous research (Vialov et al., 1981; Kruglov, 1986; Csontos and Vörös, 2004; Schmid et al., 2008; Săndulescu, 2009; Hnylko, 2011a, b, c, 2012), the following tectonic elements have been differentiated in the Ukrainian part of the orogen (Figs. 1-3): the Central Western Carpathians (part of the ALCAPA Terrane, buried under Neogene deposits of the Transcarpathian Depression) and the Central Eastern Carpathians (Marmarosh Crystalline Massif, dismembered into Marmarosh basement nappes as well as Marmarosh Klippen Zone - parts of the Tisza-Dacia Terrane); the Outer Eastern Carpathian Inner Flysch Nappes (Units) - Kamyanyi Potik, Rakhiv, Burkut, Krasnoshora, Svydovets and Chornohora nappes; the Outer Western Carpathian Inner Flysch Nappes (Units) - the Magura and Dukla nappes; the Outer Carpathian Flysch-Molasse nappes (units) - the Silesian, Subsilesian, Skyba, and BoryslavPokuttya nappes. These nappes are over-thrusted one on the other and on the Carpathian Foredeep, towards the north-east.

The accumulation of the Carpathian Flysch nappes - the ancient accretionary prism - was caused by the subduction of the Carpathian Flysch Basin basement, beneath both the ALCAPA and Tisza-Dacia terranes (Kovač et al., 1998; Csontos and Vörös, 2004; Oszczypko, 2006; Schmid et al., 2008). The Outer Western Carpathian Inner Flysch nappes (Fore-ALCAPA Magura-Dukla prism) were built in the foreland of the ALCAPA Terrane during the Paleogene. The Outer Eastern Carpathian Inner Flysch Nappes (Fore-Marmarosh flysch prism) was formed in the front of the Tisza-Dacia Terrane during the Cretaceous-Paleogene. In the Neogene, the Outer Carpathian flysch-molasse nappes were incorporated within an amalgamated inner accretionary wedge system (Hnylko, 2011a, c, 2012; Figs. 1-3).

The Kamyanyi Potik, Rakhiv, and Burkut nappes contain remnants of Jurassic-Lower Cretaceous mafic volcanic rocks of both ensialic and ensimatic origin (Lyashkevich et al., 1995), and are regarded by us as the Fore-Marmarosh Suture Zone (or part of the suture) which bounded the Tisza-Dacia Terrane from the north-east (Hnylko, 2011a). The ALCAPA Terrane is bound by the Penninic-Vahic Suture (Plašienka, 1997) from the north-east.

The Kamyanyi Potik, Rakhiv, and Burkut suture units are developed in the frontal part of the Marmarosh (Maramureş in Romanian) basement nappes (Crystalline Massif) of the Central Eastern Carpathians, and most likely correspond to the Outer Dacides-Severinides (sensu Golonka et al., 2008a, b; 


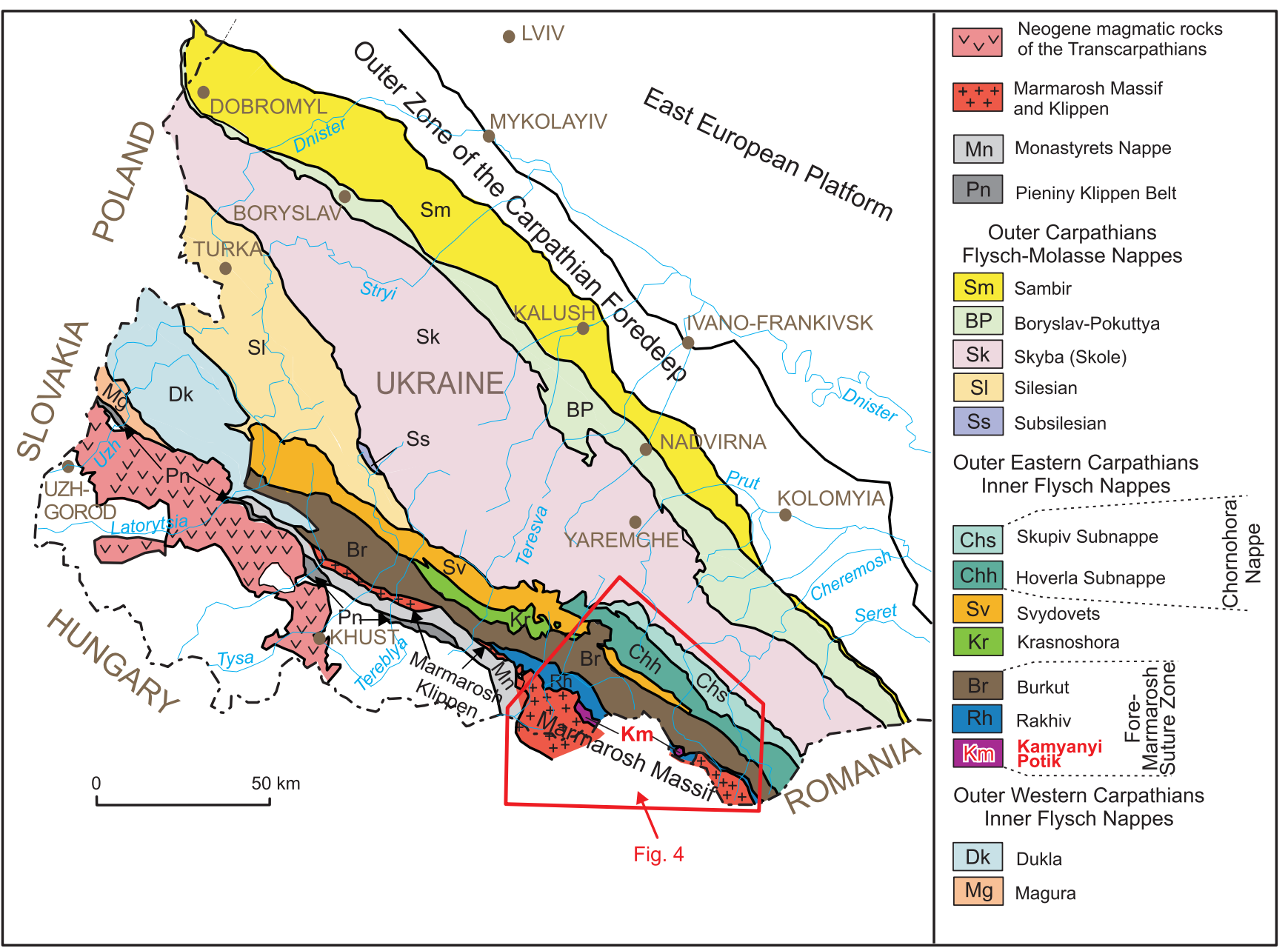

Fig. 2. The main tectonic units of the Ukrainian Carpathians (Hnylko, 2012, modified)

Săndulescu, 2009). The Kamyanyi Potik Unit is most probably the prolongation of the Black Flysch Unit of the Romanian Carpathians.

The Kamyanyi Potik Unit (Nappe) is the structurally-highest and most internal unit of the Fore-Marmarosh Nappes (flysch prism), and in many places is directly covered by the Marmarosh basement nappes. But its connection with the surrounding units is still a matter of discussion (Boyko, 1970; Vialov et al., 1981; Kruglov, 1986; Ślączka et al., 2006; Krobicki et al., 2014). Boyko (1970) interpreted this unit as being part of the Radomyr Zone of the Marmarosh Massif, Vialov et al. (1981) related it to the Rakhiv Nappe (Unit), and Kruglov (1986) and Ślączka et al. (2006) considered this unit to be a part of the Marmarosh Nappes. According to the results of the last geological mapping (Matskiv et al., 2009), which are adopted in the present work, the Kamyanyi Potik Unit forms a separate nappe, which extends from the front of the Marmarosh Nappes and consists of the Upper Jurassic/lowermost Cretaceous Chyvchyn Formation (up to $1000 \mathrm{~m}$ thick) composed mainly of basic volcanic rocks, and the Tithonian-Valanginian Kamyanyi Potik Formation (thickness $200 \mathrm{~m}$ ), which is represented by thin-bedded limestones, shales, sandstones, and conglomerate-breccias with pyroclastic material, which pass upwards into siliciclastic thick-bedded psammites and psephites (about 400 m thick). The best places to study this unit are both in the Rakhiv city vicinity (Kamyanyi Stream - stratotype of the Kamyanyi Potik
Unit) and on Chyvchyn Mt. - the highest peak of the Chyvchyn Mts. Here, this unit occupies exactly the same highest structural position as in the Outer Carpathian flysch nappes.

The other units/nappes of the Outer Eastern Carpathians Inner Flysch Nappes (sensu Hnylko, 2012) are represented by the Rakhiv, Burkut ( $\approx$ Porkulets), Krasnoshora, Svydovets and Chornohora nappes (Figs. 2-4).

The Rakhiv Nappe is formed exclusively of the Early Cretaceous Rakhiv (Sinaya in Romania) Formation (about 500 m thick), dipping generally towards the south-west under the Kamyanyi Potik Nappe and overthrusted on the Porkulets ( $\approx$ Burkut) Nappe (according to Kruglov, 1986; see also Ślączka et al., 2006 with references therein). The Rakhiv Formation consists of calcareous hemipelagites, thin- and medium-bedded turbidites, and locally of Barremian-Aptian thick-bedded psammites.

The Burkut Nappe in the southeastern section of the Ukrainian Carpathians, east of the Luzhanka River, forms a belt (up to $20 \mathrm{~km}$ wide) of Cretaceous sedimentary successions. These successions consist of Barremian-Albian clay-silt dark grey hemipelagites, contourites, rarely turbidites (Bila Tysa Formation, thickness $\sim 1000 \mathrm{~m}$ ), Albian thick-bedded sandy turbidites (Burkut Formation, thickness $\sim 1000 \mathrm{~m}$ ), and thick lenses of Albian Bronka-Bogdan conglomerates. West of the Luzhanka River, the Lower Cretaceous deposits pass upwards into Cenomanian-Turonian variegated marls (Sukhiv Formation, thick- 


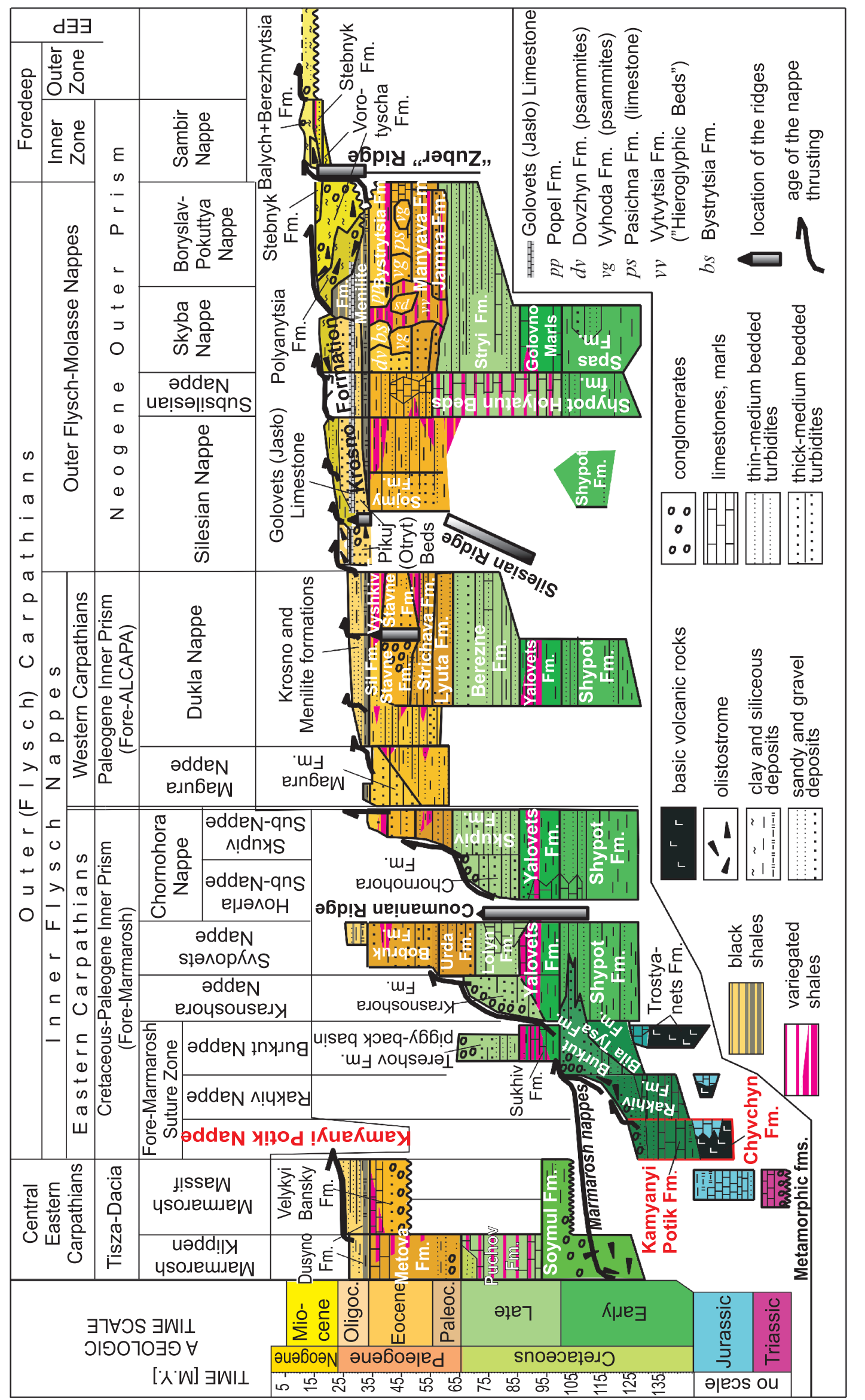




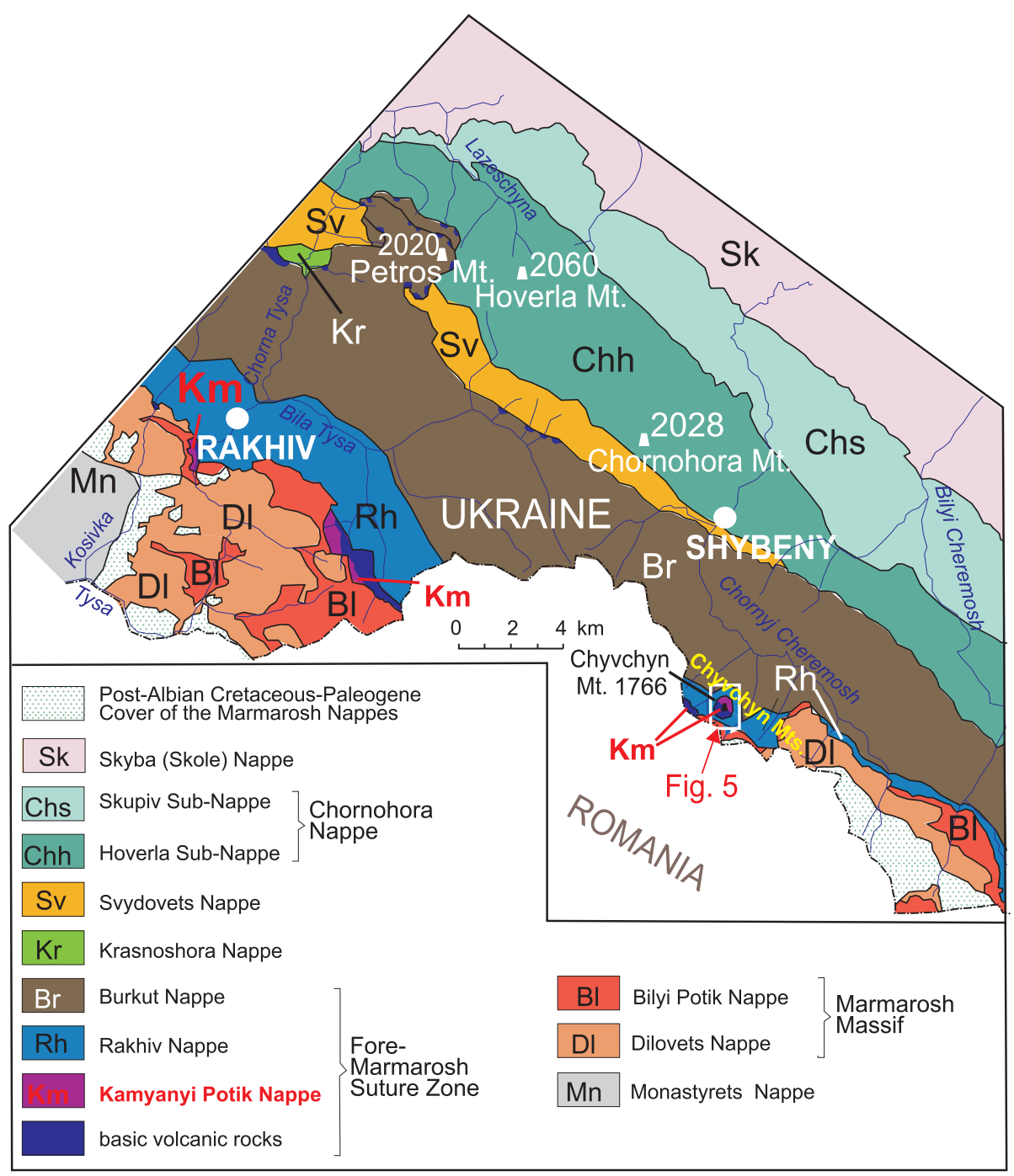

Fig. 4. The main tectonic units of the SE part of the Ukrainian Carpathians and the location of the Chyvchyn area

Compiled by Hnylko (2011a) on the base of Vialov et al. (1981), Kruglov (1986), Matskiv et al. (2009) (see also Krobicki et al., 2014: fig. 1)

ness 100-200 m) and Senonian sandy deposits (Tereshov Formation, thickness 600 m; Fig. 3).

At the base of the Burkut Nappe, as indicated earlier, tectonic klippen of Jurassic-Early Cretaceous mafic volcanic rocks (Trostyanets Formation) of both oceanic and continental origin are present (Lyashkevich et al., 1995).

The Burkut Nappe is thrusted onto the Krasnoshora Nappe ( $\approx$ Luzhanka Sub-Nappe of the Dukla Nappe according to Kruglov, 1986), represented by the series of narrow thrust sheets. These thrust sheets comprise: Lower Cretaceous hemipelagites (black, dark grey claystones) and sandy medium-bedded quartzitic turbidites (Shypot Formation, 100-200 m thick); Cenomanian-Turonian pelagic/hemipelagic deep-water variegated shales (Jalovets Formation $\sim 50 \mathrm{~m}$ thick); Senonian coarse-grained, mainly psammite, turbidites (Krasnoshora Formation) up to $500 \mathrm{~m}$ thick.

The Svydovets Nappe ( $\approx$ Blyznytsia Sub-Nappe of the Dukla Nappe, according to Kruglov, 1986) comprises: Lower Cretaceous black shales and quartzitic turbidites (Shypot For- mation); Upper Cretaceous pelagic/hemipelagic variegated shales (Yalovets Formation) and dark grey claystones, marls, and psammites (Lolyn Formation $\sim 500 \mathrm{~m}$ thick); Senonian-Paleocene sandy thick- and medium-bedded turbidites (Urda Formation 1000 m thick); Paleocene-Eocene sandy predominantly thick-bedded turbidites (Bobruk Formation $\sim 1500 \mathrm{~m}$ thick) and minor extensions in the outer thrust sheet of the nappe Oligocene deposits (Menilite and Krosno formations; Fig. 3).

The Chornohora Nappe is a prolongation of the Audia Nappe, occurring in Romania. It is subdivided into the inner (southern) Hoverla Sub-Nappe and the outer (northern) Skupiv Sub-Nappe. The Hoverla Sub-Nappe comprises stacked narrow thrust sheets, which consist of the Lower Cretaceous black deposits (Shypot Formation), Upper Cretaceous variegated hemipelagic shales (Yalovets Formation), and sandy predominantly thick-bedded turbidites (Chornohora Formation 1000 m thick). The Skupiv Sub-Nappe consists of Cretaceous black deposits (Shypot Formation), variegated hemipelagic shales 


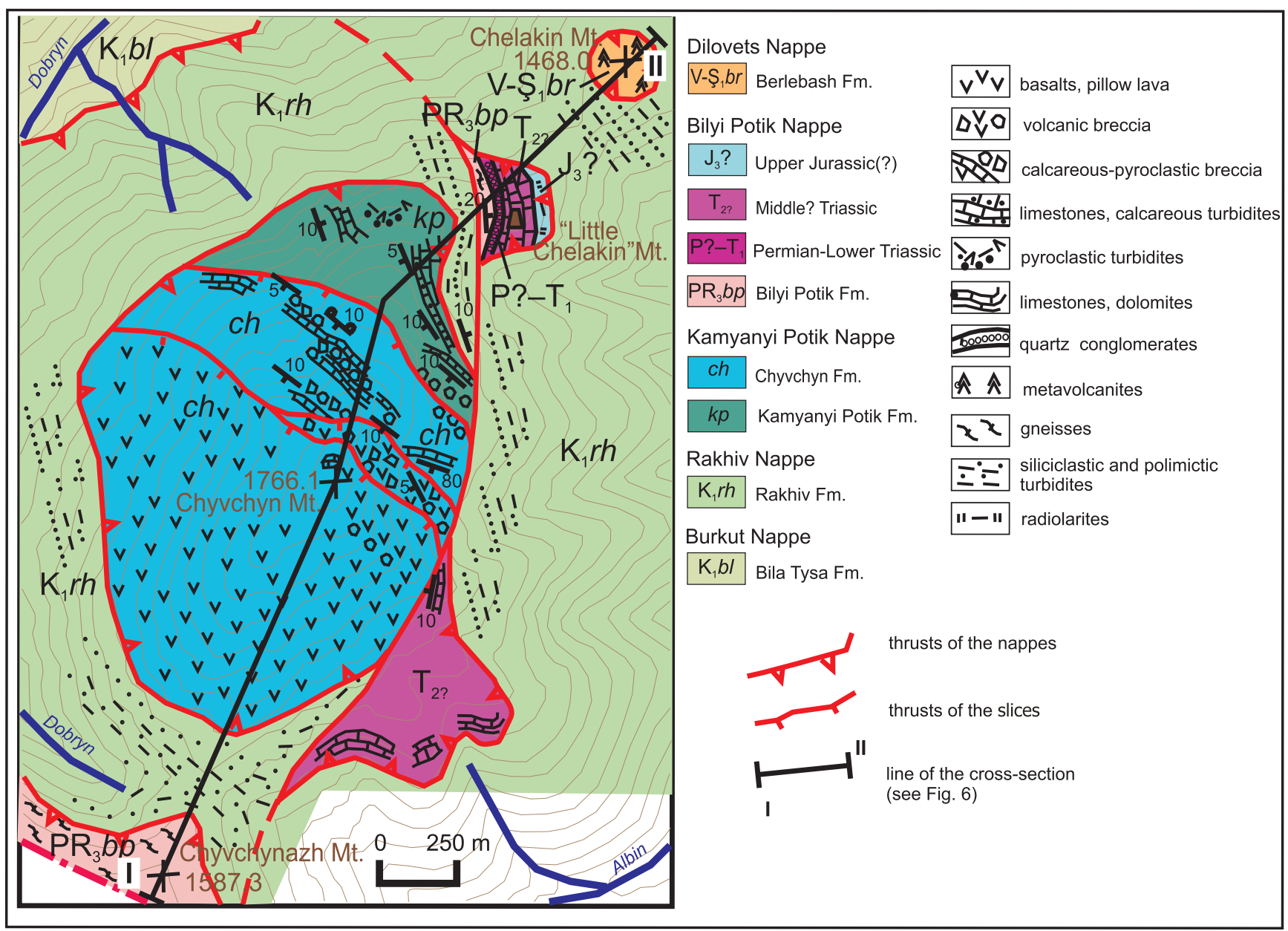

Fig. 5. Geological map of the Chyvchyn Mount area

(Yalovets Formation), and Senonian sandy medium- and thick-bedded turbidites (Skupiv Formation $\sim 1000 \mathrm{~m}$ thick). The Paleocene-Eocene sedimentary succession (700-800 m thick) is composed of medium- to thick-bedded flysch sandstones and variegated shales. The Oligocene Menilite and Krosno formations (up to $200 \mathrm{~m}$ thick) extend locally in the outer narrow thrust sheets of the Skupiv Sub-Nappe.

\section{STRUCTURE OF THE CHYVCHYN MOUNT AREA}

Our geological mapping, carried out in August 2012, showed that the volcano-sedimentary complex of Chyvchyn Mt. (1766.1 m) (Figs. 5-8A, B) forms the tectonic klippe that covers the Early Cretaceous flysch (Rakhiv Formation of the Rakhiv Nappe), and is complicated by the four small tectonic thrust slices (Figs. 5 and 6). The previous geological maps (Zapałowicz, 1886; Pazdro, 1934; Byzova et al., 1964; Matskiv et al., 2009) interpreted the complex of Chyvchyn Mt. also as a klippe, but it was not determined whether or not the tectonic trust slices were part of this klippe. Additionally, several geologists (Zapałowicz, 1886; Limanowski, 1905; Książkiewicz and Sokołowski, 1934; Pazdro, 1934; Horwitz, 1935; Byzova et al., 1964; Lomize, 1968) thought that the volcano-sedimentary complex of Chyvchyn Mt. is overturned, however, our sedi- mentological observations, such as those of cross-laminated calcareous sandstones that become finer-grained upwards, indicate normal tectonic positions of the deposits in these thrust slices.

The structurally-lowest first thrust slice (100-200 m thick) crops out on the northern slope of Chyvchyn Mt. (Hnylko et al., 2007) and is developed as thin-bedded light and dark grey micritic limestones with lenses of dark cherts, and is interbedded with coarse/fine-grained calcareous pyroclastic turbidites (flysch) (Kamyanyi Potik Fm. - Figs. 5, 6 and 7C, D ). It is similar to the stratotype of this formation in the Kamyanyi Potik Stream, near Rakhiv (Krobicki, 2012; Krobicki et al., 2014). Near the trail that goes around the north side of the Chyvchyn Mt., there are outcrops of pyroclastic flysch - turbidites with graded textures that contain significant amounts of volcanic material. This flysch most likely should be attributed to the Kamyanyi Potik Formation. Such unique flysch-type rocks are usually developed as more or less thin intercalations, both of coarse- and fine-grained calcareous pyroclastic beds within thin-bedded light and dark grey micritic limestones, sometimes with lenses of dark cherts.

Based on the sedimentological features typical for turbiditic systems we can interpret it as the distal equivalent of the deep-marine lobes of turbidite fans. On the other hand, more coarse-grained pyroclastic sandstones and fine-grained pyroclastic conglomerates could represent a more proximal-type of 


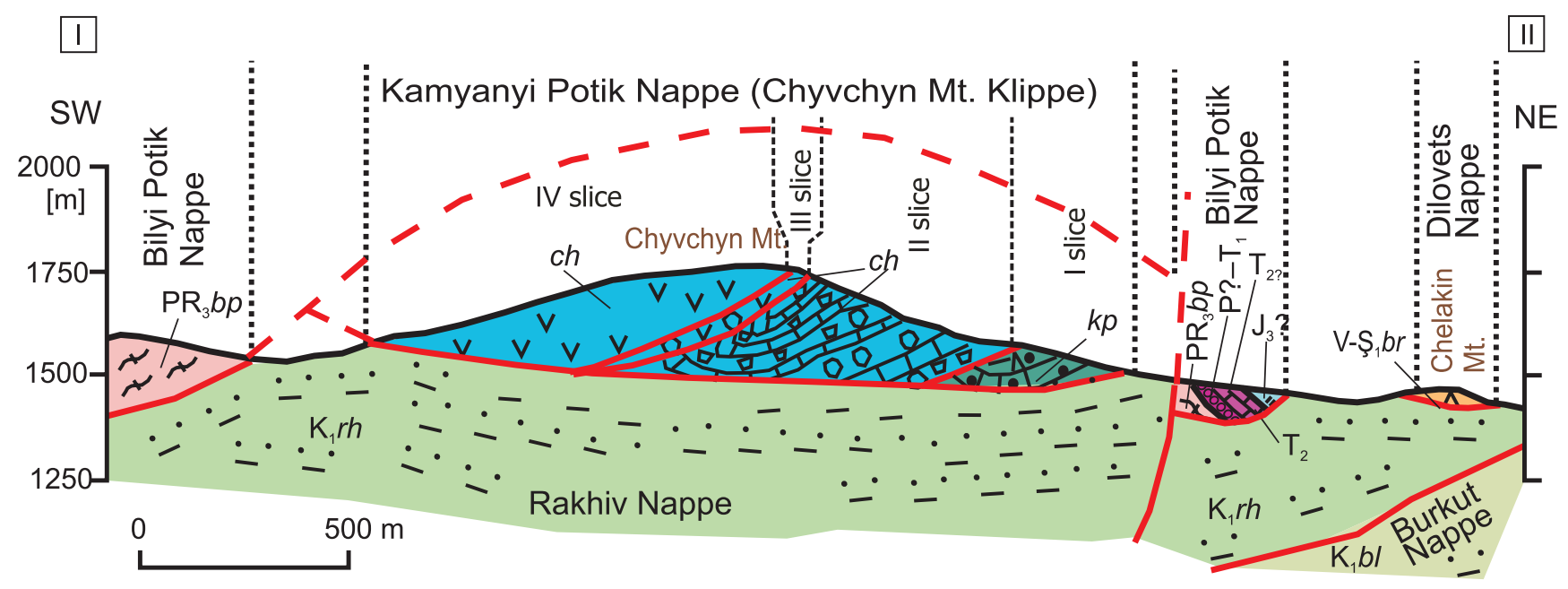

Fig. 6. Geological cross-section of the Chyvchyn Mount area along the I-II line (see Fig. 5)

For other explanations see Figure 5

turbiditic currents. All these types of rocks have typical flyschcharacter features, including a sharp base of beds with clasts of allochthonous materials, graded bedding, ripple-lamination, and an increase in the pelagic character of the topmost part of the beds (up to micritic limestones). The deposits of the first thrust slice lie subhorizontal and form a gentle syncline.

The second thrust slice (250-300 m thick) reaches the surface on the northern slope of Chyvchyn Mt. It is very gently thrust over the first thrust slice to the north-east, and is gently overthrusted by the third thrust slice from the south-west. It comprises calcareous-pyroclastic breccias, with blocks of micritic and organodetrital limestone (usually up to $1.5 \mathrm{~m}$ but occasionally even up to 20 m-across, sometimes with Late Jurassic/earliest Cretaceous corals - Lomize, 1968), basalts (even as pillow lava fragments), and small fragments of red cherts, which occur within a volcanic/tuffitic matrix (Fig. 7E-G). In the same thrust slice, coral limestones with basalt fragments and pyroclastic intercalations, as well as cross-laminated calcareous sandstones - deposited probably between the actions of mass movements - are observed. Judging by the chaotic structure of this calcareous-pyroclastic breccia, it represents extremely proximal mass movements, most probably as submarine debris flows. These deposits dip very gently to the south-west, but on the eastern slope of Chyvchyn Mt., directly under the thrust plane of the third thrust slice, the dip changes to subvertical, which can be explained by the thrust-related folding of parautochthonous rocks (Figs. 5 and 6).

The third thrust slice is a small tectonic lens (up to $40 \mathrm{~m}$ thick) which comes to the surface near the top of Chyvchyn Mt., and is filled by breccia with volcanic clasts (up to $1 \mathrm{~m}$ in size) of effusive rocks (locally as pillow lava fragments) and rare limestones, in pyroclastic or volcanic matrix.

The fourth thrust slice (200-250 m thick) forms the highest one in the structure of Chyvchyn Mt. and crops out on the Chyvchyn summit and its southwestern slope, and is represented by massive green-grey and dark basalts with typical pillow lava structures (Fig. 8A, B). It is gently thrust over the third thrust slice. Basaltic lava layers gently dip to the south-west. Near the top of Chyvchyn Mt., basalts are depositionally overlapped by micritic grey limestones up to $15 \mathrm{~m}$ thick. These limestones lie subhorizontally and crop out as a small (few tens of metres) "caps on basalts" - the erosional remnants of the limestone beds.

Byzova et al. (1964), Lomize (1968) and Matskiv et al. (2009) attributed the rocks of the Chyvchyn Mt. Klippe to the Upper Jurassic/lowermost Cretaceous Chyvchyn Formation. In our opinion, according to the lithostratigraphical scheme, basalts and breccias only of the second, third, and fourth thrust slices belong to the Chyvchyn Formation (ch; see Figs. 5 and 6 ), and micritic laminated limestones and calcareous pyroclastic turbidites of the first thrust slice belong to the Kamyanyi Potik Formation (kp).

Flysch deposits, represented by the polymictic or siliciclastic medium-grained turbidite sandstones which underlie the Chyvchyn Mt. Klippe, belong to the upper part of the Lower Cretaceous Rakhiv Formation $\left(\mathrm{K}_{1} r h\right)$. The clastic material consists of quartz, feldspar, mica, and fragments of metamorphic and sedimentary rocks, similar to the Marmarosh Massif ones. The Rakhiv Formation deposits comprise the Rakhiv Nappe, which gently thrusts onto the outer Burkut Nappe. Byzova (1965) described, within the Rakhiv Formation, in the upper parts of the Dobryn and Albin streams, "horizons with inclusions" up to $120 \mathrm{~m}$ thick, with sedimentary slumps of redeposited flysch, basalts, and metamorphic rocks. The slumps, developed under the Chyvchyn Mt. Klippe in the front of the Marmarosh Nappes, were most probably derived from the Kamyanyi Potik and Marmarosh nappes. The Burkut Nappe, in the Chyvchyn Mt. area, is composed of the grey, mainly medium-bedded siliciclastic mica flysch (the Lower Cretaceous Bila Tysa Formation, $\mathrm{K}_{1} \mathrm{bl}$ ) without distinct Bouma textures, however, with well-defined cross and convolute lamination.

South from Chyvchyn Mt., near the border between Ukraine and Romania (Chyvchynazh Mt., $1587.3 \mathrm{~m}$ ), are developed crystalline Precambrian rocks of the Marmarosh Massif, represented by the two-mica gneisses and schists of the Bilyi Potik Formation $\left(\mathrm{PR}_{3} b p\right)$. These rocks belong to the Bilyi Potik Nappe (Marmarosh Lower Nappe, according to Matskiv et al., 2009), which is thrusted upon the Rakhiv Unit. The structural relationship between the Marmarosh Massif and the Chyvchyn Mt. Klippe is unclear, since they are separated by the Rakhiv Formation (Figs. 5 and 6). 
A
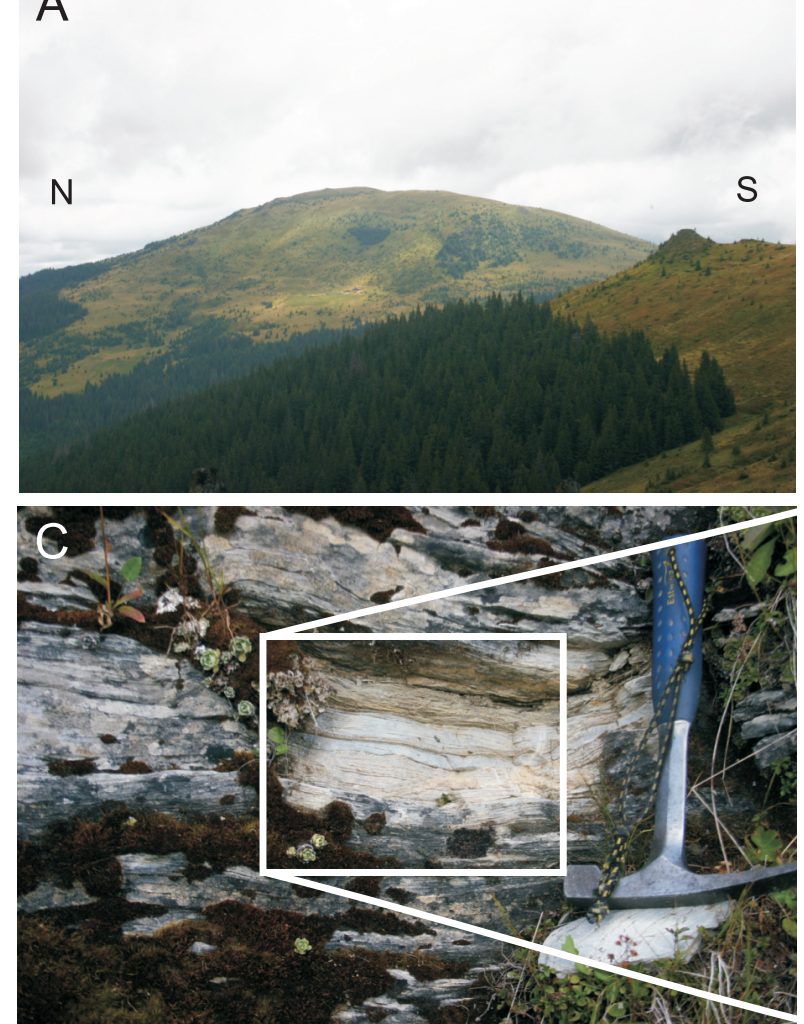

$\mathrm{E}$
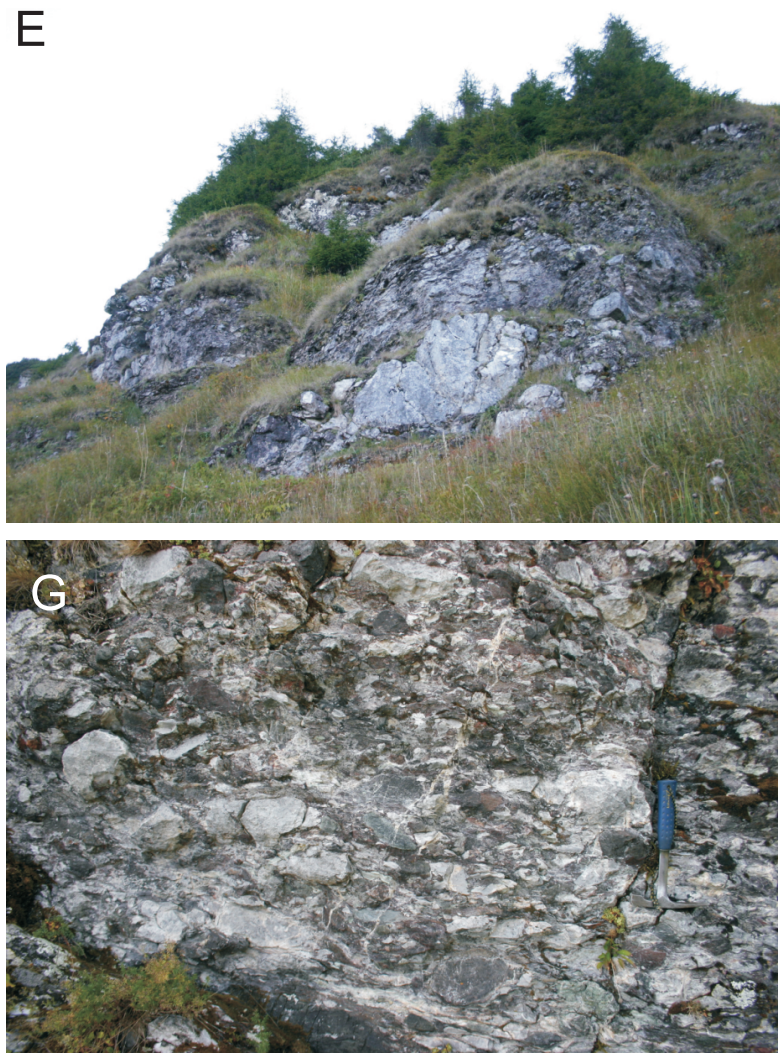

B

$S$

$\mathrm{N}$
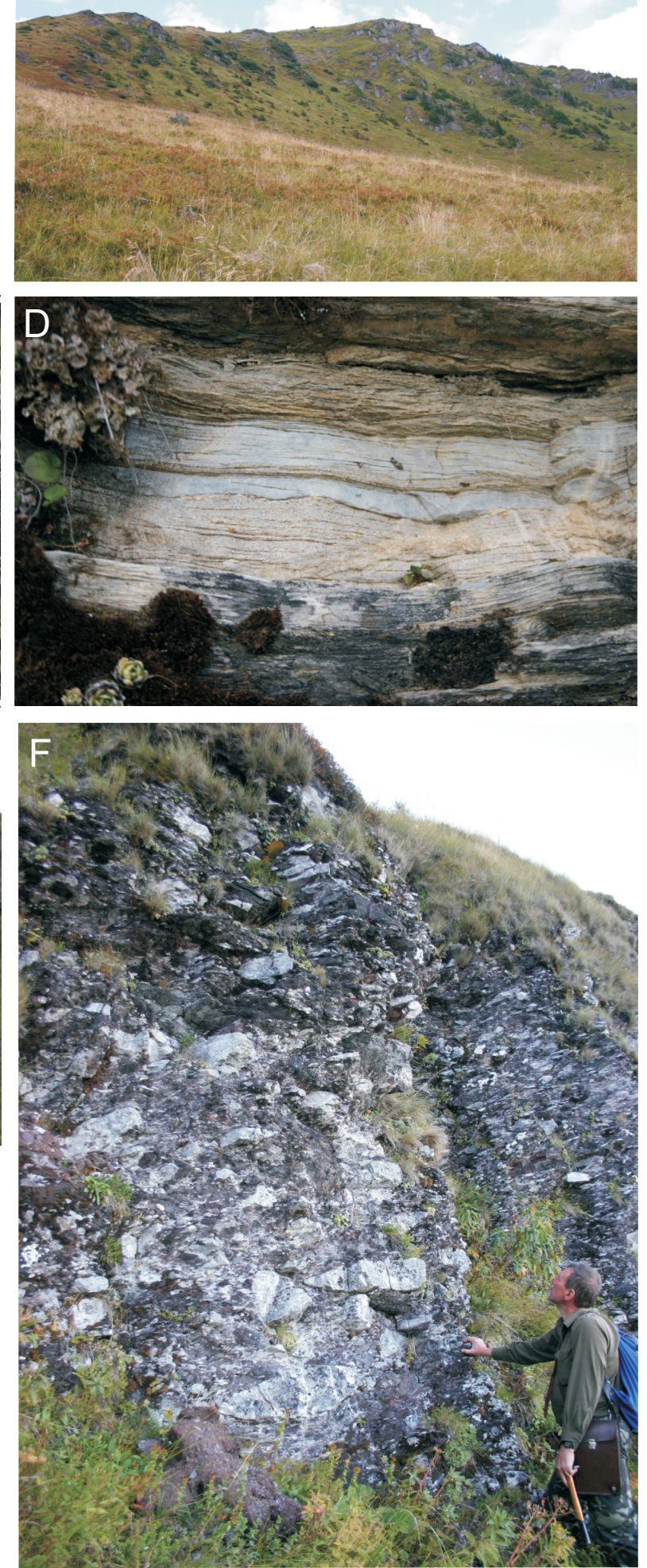

Fig. 7A - Chyvchyn Mount (1766.1 m a.s.I.) - view from the south; B - Chyvchyn Mount - view from the east on the basalt rocks; C, D - thin-bedded limestones with pyroclastic intercalations (first trust slice); E-G - pyroclastic/volcanic breccias (second trust slice) 

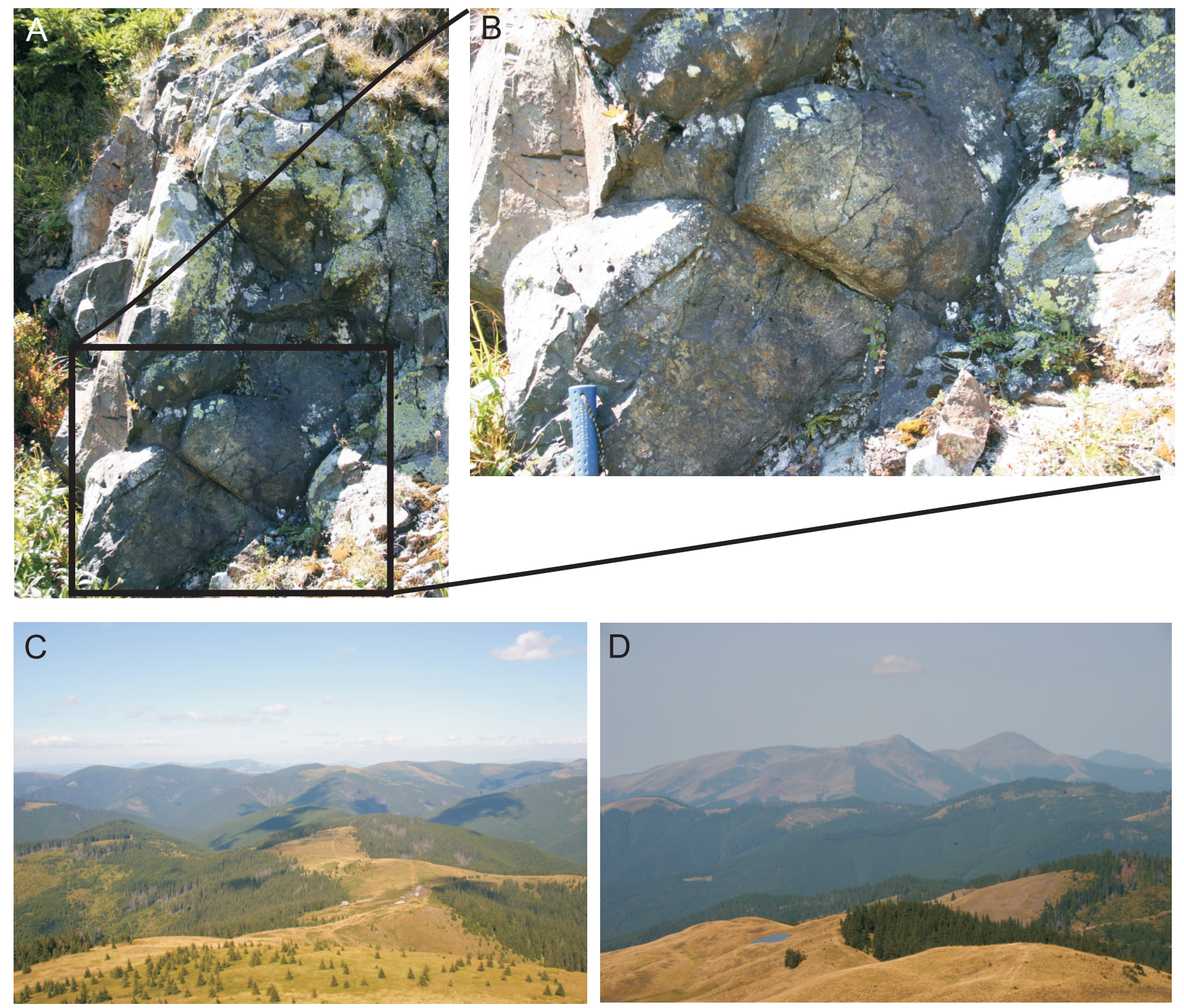

Fig. 8A, B - pillow lava basalts (fourth trust slice); C - view on the Chelakin Mount (1468.0 m); D - view on the Farcaul and Mihailecul mounts (Romanian Carpathians)

To the north-east of Chyvchyn Mt. is a small hill ("Little Chelakin"), composed of the following rocks (Fig. 8C):

- Precambrian schists and gneisses of the Bilyi Potik Formation (thickness of $\sim 40 \mathrm{~m}$ );

- Permian(?) - Lower Triassic quartzitic grey and red conglomerates, found only in pebbles;

- Middle(?) Triassic grey non-laminated and massive limestones and dolomites (thickness of $\sim 50 \mathrm{~m}$ );

- Upper Jurassic(?) layered red cherts.

It seems that these four stratal units, lying one on another, very gently dip to the east and comprise the Little Chelakin Klippe $(\sim 250 \times 350 \mathrm{~m})$ of the Bilyi Potik Nappe (Marmarosh Lower Nappe) which structurally overlies the Rakhiv Unit. However, the Rakhiv Formation (parautochthon) thrusts along the subsequently formed fault on the Little Chelakin Klippe from the south-west, and thus the Rakhiv Early Cretaceous flysch on the slope of Chyvchyn Mt. is elevated above the Bilyi Potik crystalline schists (Figs. 5 and 6).
The klippe of the Bilyi Potik Nappe is developed on the south-east slope of Chyvchyn Mt. (Matskiv et al., 2009). It consists of Middle(?) Triassic, grey, non-laminated, massive limestones and dolomites (Fig. 5).

About $1650 \mathrm{~m}$ to the north-east from the Chyvchyn summit there is also a small $(250 \times 250 \mathrm{~m})$ tectonic klippe of the Dilovets Nappe (Marmarosh Upper Nappe - Matskiv et al., 2009), which builds Chelakin Mt. (1468.0 m) (Fig. 8C). This klippe is composed of the metamorphosed, foliated, and acidic volcanic rocks of the Berlebash Formation (V-Ş, $1 b r)$, and structurally overlaps the Rakhiv Unit (Figs. 5 and 6).

\section{DISCUSSION}

The volcano-sedimentary complex of the Chyvchyn Mt. Klippe does not form a single stratigraphic sequence, as was previously assumed (Byzova et al., 1964; Lomize, 1968; 
Matskiv et al., 2009), and is clearly subdivided into several tectonic thrust slices. Three rock associations, distributed into several tectonic thrust slices of the Chyvchyn Mt. Klippe, can be distinguished in this complex:

- basalts and volcanic breccias (fourth and third thrust slices) of the lower(?) part of the Chyvchyn Formation;

- debris-flow sedimentary and volcano-sedimentary breccias with blocks of limestone, basalt, small fragments of red cherts within volcanic/tuffitic matrix and coral limestones with basalt fragments and pyroclastic intercalations (second thrust slice) - the upper(?) part of the Chyvchyn Formation;

- thin-bedded micritic limestones, with cherts interbedded with coarse/fine-grained calcareous pyroclastic turbidites (flysch) (first thrust slice) - the Kamyanyi Potik Formation.

It is assumed that the three rock associations of the Chyvchyn Mt. Klippe are genetically related. They can be attributed to the Kamyanyi Potik Unit (Nappe), although direct interrelation between the Chyvchyn Mt. Klippe and the Marmarosh basement nappe is not observed in the area. These associations probably were formed in the Late Jurassic-Early Cretaceous into several different parts of the Outer Dacides-Severinides Carpathian basin, and can be considered as a facies. In our reconstruction, these facies have continual transitions, from very proximal types of debris flow through flysch-type facies of coarse- and fine-grained pyroclastic turbidites, up to flows of massive basaltic pillow lavas on the other side. Pyroclastic flysch is not so common among world-wide turbiditic systems of different ages (e.g., White, 2000; Jackson et al., 2008; Kralj, 2012). In contrast to the intercalations of thin tuffitic layers, which frequently occur in the Carpathian flysch deposits (e.g., the Podhale Flysch Paleogene - Roniewicz and Westwalewicz-Mogilska, 1974; Outer Flysch Carpathians - Cieszkowski et al., 2006), the huge amount of pyroclastic material necessary for the origin of pyroclastic turbidities indicates strong volcanic activity in the source area and in its proximity. Additionally, depending on its geochemical character, it is connected with special kinds of geotectonic regime, manifested by voluminous pyroclastic material production.

At this stage of research, we can argue that the volcanic formation of the Chyvchyn Mt. Klippe, according to existing petrochemical data (Lyashkevich et al., 1995), most likely formed on oceanic crust. The Chyvchyn Mt. Klippe, as a fragment of the Kamyanyi Potik Unit, can be attributed to the Fore-Marmarosh Suture Zone - a trace of the Late Jurassic-Early Cretaceous (sub)oceanic basin (part of the embryonic Outer Carpathian Basin) which existed between the Tisza-Dacia Terrane and Eurasia. This basin was obviously characterized by sharply differentiated depths: from shallow (as indicated by the remnants of corals and organodetrital limestones on the Chyvchyn Mt. Klippe) - to deep (fragments of the red cherts (radiolarites?) in breccia from the Chyvchyn Mt. Klippe). In our case, the Juras$\mathrm{sic} /$ Cretaceous volcanic activity in these parts of the Carpathian basins could be one of the best key to understanding the geodynamic history of the northernmost part of Tethys. The final clarification of this problem is impossible without the correlation of the Chyvchyn Mt. structures with the volcanic formations of the Romanian Carpathians (especially the Farcaul and Mihailecul mounts - Fig. 8D; lanovici et al., 1968; Săndulescu, 1982; Krobicki et al., 2014).
The subduction of the Outer Carpathian sedimentary basin basement under the Marmarosh Massif (Tisza-Dacia Terrane), which probably began in the late Early Cretaceous, led to the elevation and denudation of the Marmarosh Massif, onset of the flysch sedimentation in the Outer Carpathian Basin in the front of Marmarosh Nappes (upper parts of the sedimentary successions of the Kamyanyi Potik Unit; as well as the Rakhiv Fm., Bila Tysa Fm., and the Burkut sandy turbidites), and subsequently led to the formation of the Fore-Marmarosh Flysch accretionary prism. The first addition to the flysch prism, added in the Early Cretaceous, was the Kamyanyi Potik Nappe, which began to supply clastic materials, including olistoliths of basalt, into the more external Rakhiv flysch sub-basin. Subsequently, in the Early Cretaceous-Paleogene, Rakhiv, Burkut, Krasnoshora, Svydovets, and Chornohora (Inner-Flysch Nappes - ForeMarmarosh prism) were formed step-by-step in the front of the Tisza-Dacia Terrane (Hnylko, 2012). The sedimentary basin basement was subducted, and only small tectonic lenses of basic volcanic rocks (including thrust slices of the Chyvchyn Mt. Klippe) were scraped from the subducted plate and added to the Fore-Marmarosh accretionary prism.

\section{CONCLUSIONS}

1. Chyvchyn Mt. is constructed by the Kamyanyi Potik Unit (Nappe) and forms the separate a tectonic cap (Chyvchyn Mt. Klippe) that structurally overlaps the Early Cretaceous flysch of the Rakhiv Unit (Nappe). The Kamyanyi Potik Unit consists of the Upper Jurassic/earliest Cretaceous Chyvchyn Formation, which is composed mainly of basic volcanic rocks, and the Tithonian-Valanginian Kamyanyi Potik Formation, which is represented by limestones, shales, sandstones, and conglomerates-breccias with pyroclastic material. The Kamyanyi Potik Unit is the structurally-highest and most internal unit of the Ukrainian Outer Eastern Carpathians, which is overlapped by Marmarosh (Maramureş in Romanian) basement nappes (crystalline massif) of the Central Eastern Carpathians. This unit belongs to the Fore-Marmarosh flysch accretionary prism.

2. Our geological mapping showed that the Chyvchyn Mt. Klippe is composed of the four small tectonic thrust slices. The structurally-lowest, first thrust slice (100-200 m in thickness) is developed as micritic limestones, with cherts interbedded by pyroclastic turbidites (flysch) (Kamyanyi Potik Fm.). The second thrust slice (250-300 m thick) is built mostly of calcareous-pyroclastic breccia (submarine debris flow deposits), with fragments of micritic and organodetrital limestone, basalt, red cherts within volcanic/tuffitic matrix and coral limestones with basalt fragments and pyroclastic intercalations (Chyvchyn Fm.). The third thrust slice is a small tectonic lens (up to $40 \mathrm{~m}$ thick) and is filled with breccia with pyroclastic or volcanic matrix and clasts of effusive rock, and rare limestones (Chyvchyn Fm.). The fourth thrust slice (200-250 m thick) forms the highest one in the structure of Chyvchyn Mt., and is represented by massive basalts with typical pillow lava structures (Chyvchyn Fm.).

3. The volcano-sedimentary complex of the Chyvchyn Mt. Klippe is composed of three rock associations, which occur in several tectonic thrust slices: basalts and volcanic debris-flow breccias, debris-flow sedimentary and volcano-sedimentary breccias, and limestones with basalts and thin-bedded micritic limestones, with cherts interbedded with calcareous pyroclastic 
turbidites. These rock associations are a facies which probably originated in different parts of the Outer Dacide-Severinide Carpathian Basin.

4. The volcano-sedimentary formation of the Chyvchyn Mt. Klippe was formed on presumed oceanic crust, and is a remnant of the Jurassic/Cretaceous Carpathian Basin in the northern part of the Western Tethys.
Acknowledgements. The authors would like to thank the reviewers, Y.V. Koltun (National Academy of Sciences of Ukraine) and J. Michalík (Slovak Academy of Sciences), and the scientific editor T.M. Peryt for their constructive comments and useful remarks, which greatly improved the final version of the manuscript, and W. Ryłko for discussion. The research was financially supported by the Polish Geological Institute - National Research Institute (project no. 61.2301.1301.00.0).

\section{REFERENCES}

Boyko, A.K., 1970. Doverkhnepaleozoyskiy kompleks severozapadnogo okonchaniya Marmaroshskogo massiva (Vostochnyye Karpaty) (in Russian). Publishing House of Lviv University, Lviv.

Byzova, S.L., 1965. Podvodno-opolznevyye obrazovaniya v nizhnemelovykh otlozheniyakh Chyvchynskikh gor (Vostochnyye Karpaty) (in Russian). Byuletin Moskovskogo Obshchestva Ispytateley Prirody. Otdel Geologicheskiy, (1): 164-176.

Byzova, S.L., Vidyakin, N.S., Dobrynina, V.Y., Rudakov, S.G., Slavin, V.I., 1964. Otchet po geologicheskoy syomke masshtaba 1:50 000 listov Shibeny, Grynyava, Perkalab, Shepot i masshtaba 1:25 000 Chivchinskogo kristalicheskogo massiva. (Konechnyy otchet). Moskva - Kiyev (in Russian). Unpublished report. Archives of PGO "Zapukrgeologiya", Lviv.

Cieszkowski, M., Środoń, J., Waśkowska-Oliwa, A., Leśniak, T., 2006. Bentonitized tuffites in the Lower Eocene deposits of the Subsilesian Unit (Western Outer Carpathians, Poland): lithology, stratigraphic position and mineral composition. Annales Societatis Geologorum Poloniae, 76: 197-214

Csontos, L., Vörös, A., 2004. Mesozoic plate tectonic reconstruction of the Carpathian region. Palaeogeography, Palaeoclimatology, Palaeoecology, 210: 1-56.

Gnylko, O., 1999. Cretaceous evolution of the Fore-Marmarosh Flysch Basins (Ukrainian Carpathians). Geologica Carpathica, 50: 26-27.

Golonka, J., Gahagan, L., Krobicki, M., Marko, F., Oszczypko, N., Ślączka, A., 2006. Plate tectonic evolution and paleogeography of the circum-Carpathian region. AAPG Memoir, 84: 11-46.

Golonka, J., Krobicki, M., Waśkowska-Oliwa, A., Vašíček, Z., Skupien, P., 2008a. Main paleogeographic elements of the West Outer Carpathians during Late Jurassic and Early Cretaceous times (in Polish with English summary). Geologia, 34: 61-72.

Golonka, J., Vašíček, Z., Skupien, P., Waśkowska-Oliwa, A., Krobicki, M., Cieszkowski, M., Ślączka, A., Słomka, T., 2008b. Lithostratigraphy of the Upper Jurassic and Lower Cretaceous deposits of the western part of the Outer Carpathians (discussion proposition) (in Polish with English summary). Geologia, 34: 9-31.

Hnylko, O.M., 2011a. Tectonic zoning of the Carpathians in terms of the terrane tectonics. Section 1. Main units of the Carpathian Building (in Ukrainian with English summary). Geodynamika, 10: $47-57$.

Hnylko, O.M., 2011b. On the shear zone in the western part of the Ukrainian Carpathians (in Ukrainian with English summary). Geolohiya i Geokhimiya Horyuchykh Kopalyn, (3-4): 68-80.

Hnylko, O.M., 2011c. Terrane analysis and geological evolution of the Carpathians (in Ukrainian with English summary). Visnyk of the Lviv University, Geological Series, 25: 174-188.

Hnylko, O.M., 2012. Tectonic zoning of the Carpathians in terms of the terrane tectonics. Article 2. The Flysch Carpathian - ancient accretionary prism (in Ukrainian with English summary). Geodynamika, 12: 67-78.

Hnylko, O., Matskiv, B., Ternavsky, M., 2007. On geological setting and forming conditions of the Triassic-Jurassic deposits from Chyvchynian Mountains (Ukrainian Carpathians) (in Ukrainian with English summary). Geolohiya i Geokhimiya Horyuchykh Kopalyn, (2): 63-75.

Horwitz, L., 1935. Un essai de raccordement des unites tectoniques des Karpates orientales avec celles des Karpates occidentales (in Polish with French summary). Sprawozdania Polskiego Instytutu Geologicznego, 8: 135-169.

Ianovici, V., Rădulescu, D., Patrulius, D., 1968. Harta geologică, 4 Vişeu, Bucuresti.

Jackson, T.A., Scott, P.W., Donovan, S.K., Pickerill, R.K., Portell, R.W., Harper, D.A.T., 2008. The volcaniclastic turbidites of the Grand Bay Formation, Carriacou, Granadines, Lesser Antilles. Caribbean Journal of Science, 44: 116-124.

Jankowski, L., Kopciowski, R., Ryłko, W., eds., 2007. Geological map of the Outer Carpathians: borderland of Ukraine and Romania 1:200 000. Państwowy Instytut Geologiczny, Warszawa.

Kovač, M., Nagymarosy, A., Oszczypko, N., Ślączka, A., Csontos, L., Marunteanu, M., Matenco, L., Márton, M., 1998. Palinspastic reconstruction of the Carpathian-Pannonian region during the Miocene. In: Geodynamic Development of the Western Carpathians (ed. M. Rakús): 189-217. Geological Survey of Slovak Republic, Bratislava.

Kralj, P., 2012. Facies architecture of the Upper Oligocene submarine Smrekoves stratovolcano, Northern Slovenia. Journal of Volcanology and Geothermal Research, 247-248: 122-138.

Krobicki, M., 2012. Wycieczka terenowa. In: JURASSICA X: Jurajsko-dolnokredowe utwory pienińskiego pasa skałkowego i obszarów przyległych (Ukraina - Zakarpacie, wschodnia Słowacja) (in Polish). Abstrakty i przewodnik wycieczki terenowej, Rakhiv-Beňatina 25-30.06.2012: 31-56, 100-104, 127-130.

Krobicki, M., Hnylko, O., Feldman-Olszewska, A., Iwańczuk, J., 2014. Tectono-stratigraphic position of the Kaminnyi Potik Unit in the Ukrainian Carpathians and volcanogenic rocks of Mt Chyvchyn. In: First International Congress on Stratigraphy, STRATI 2013 (eds. R. Rocha, J. Pais, J.C. Kullberg and S. Finney): 533-537. Springer.

Kruglov, S.S., ed., 1986. Tektonika Ukrainskikh Karpat (obyasnitelnaya zapiska k tektonicheskoy karte Ukrainskikh Karpat m-ba 1:200 000) (in Russian). Naukova Dumka, Kiev.

Książkiewicz, M., Sokołowski, S., 1934. Remarques sur la géologie des montagnes de Czywczyn (Carpates Orientales). Rocznik Polskiego Towarzystwa Geologicznego, 10: 506-518.

Kulchytskyi, J.O., Maksimov, O.V., 1961. Stratyhrafiya kreydovykh vidkladiv khrebta Chornohora v Ukrainskykh Karpatakh (in Ukrainian). Dopovidi Akademiyi Nauk URSR, 8: 1066-1068.

Lyashkevich, Z.M., Medvedev, A.P., Krupskiy, Y.Z., Varichev, A.S., Tymoshchuk, V.P., Stupka, O.O., 1995. Tectonomagmatic evolution of Carpathians (in Russian with English summary). Naukova Dumka, Kiev. 
Limanowski, M., 1905. Coup - d'oeil sur l'architecture de Carpathes (in Polish). Kosmos, 30: 253-340.

Lomize, M.G., 1968. Pozdneyurskiy vulkanizm Vostochnykh Karpat (in Russian). Vestnik Moskovskogo Universiteta, (6): 42-58.

Matskiv, B.V., Pukach, B.D., Hnylko, O.M., 2009. Derzhavna heolohichna karta Ukrayiny m-bu 1:200 000, arkushi M 35 XXXI (Nadvirna), L 35 I (Viseu de Sus). Karpatska seriya. Heolohichna karta dochetvertynnykh utvoren (in Ukrainian). UkrDGRI, Kyiv.

Medvedev, A.P., Varitchev, A., 2000. Pra-Carpathians (Construction and de-construction) (in Ukrainian with English summary). Institute of Geology and Geochemistry of Combustible Minerals, NAS of Ukraine.

Oszczypko, N., 2006. Late Jurassic-Miocene evolution of the Outer Carpathian fold-and-thrust belt and its foredeep basin (Western Carpathians, Poland). Geological Quarterly, 50 (1): 169-194.

Pazdro, Z.T., 1934. Les Montagnes de Czywczyn (in Polish with French summary). Rocznik Polskiego Towarzystwa Geologicznego, 10: 3-149.

Plašienka, D., 1997. Cretaceous tectonochronology of the Central Western Carpathians, Slovakia. Geologica Carpathica, 48: 99-111.

Roniewicz, P., Westwalewicz-Mogilska, E., 1974. Tuffites in the Podhale Flysch (Western Carpathians). Bulletin of the Polish Academy of Sciences, Earth Sciences, 22: 37-43.

Săndulescu, M., 1982. Contributions à la connaissance des nappes crétacées des monts du Maramureş. D. S. Institutului de Geologie şi Geofizică, 69: 83-96.
Săndulescu, M., 2009. The Black Flysch Nappe of the Maramureş East Carpathians - A "Valaisanne-Type" Tectonic Unit? Proceedings of the Romanian Academy, Series B, 1: 45-51.

Schmid, S., Bernoulli, D., Fugenschuh, B., Matenco, L., Schefer, S., Schuster, R., Tischler, M., Ustaszewski, K., 2008. The Alpine-Carpathian-Dinaric orogenic system: correlation and evolution of tectonic units. Swiss Journal of Geosciences, 101: 139-183.

Ślączka, A., Kruglov, S., Golonka, J., Oszczypko, N., Popadyuk, I., 2006. Geology and hydrocarbon resources of the Outer Carpathians, Poland, Slovakia, and Ukraine: general geology. AAPG Memoir, 84: 221-258.

Varitchev, A., 1997. Major and trace element geochemistry of Mesozoic igneous formation of the Ukrainian Carpathians as an indicator of paleotectonic settings. Przegląd Geologiczny, 45: 1109-1110.

Vialov, O.S., Gavura, S.P., Danysh, V.V., Leshchukh, R.J., Ponomaryova, L.D., Romaniv, H.M., Tsarnenko, P.N., Tsizh, I.T., 1981. Istoriya geologicheskogo razvitiya Ukrainskikh Karpat (in Russian). Naukova Dumka. Kiev.

Vialov, O.S., Gavura, S.P., Danysh, V.V., Lemishko, O.D., Leshchukh, R.J., Ponomaryova, L.D., Romaniv, A.M., Smirnov, S.E., Smolinskaya, N.I., Tsarnenko, P.N., 1988. Stratotipy melovykh i paleogenovykh otlozeniy Ukrainskikh Karpat (in Russian). Naukova Dumka. Kiev.

White, J.D.L., 2000. Subaqueous eruption-fed density currents and their deposits. Precambrian Research, 101: 87-109.

Zapałowicz, H., 1886. Geologische Skizze des östlichen Theiles des Pokutisch-Marmaroscher Grenz-Karpathen. Jahrbuch der k. k. Geologischen Reichsanstalt, 36: 361-591. 